\title{
Influence of digestibility of bulky forages in daily gains in penned steers using two levels of supplemented grain
}

\author{
JA Josifovich, JO Scheneiter \\ Instituto Nacional de Tecnologia Agropecuaria, Estación Experimental Agropecuaria, \\ 2700 Pergamino, Buenos Aires, Argentina
}

Digestibility of bulky forages directly affects intake and animal gains in beef animals according to Minson, (1990, Forage in ruminant nutrition, 95-121). In general there is more information about high quality forage digestibility than about low quality stubble, straw or residues digestibility. In the Argentine temperate area there are large amounts of agricultural residues originated from small grains, corn and soybeans, that can be utilised for beef animal feed. High quality hay is very difficult to get due to the climatic conditions in spring and summer, when heavy rainfalls are not uncommon.

Considering the facts above mentioned, and according to data obtained over 20 years at Pergamino Experiment Station, the relationship among the DMIVD (Dry matter in vitro digestibility) of several forages and ADG (Average daily gain) was studied. In all cases British bred steers $250-300 \mathrm{~kg}$ initial weight, were pen fed during winter months at two grain supplement levels, 2.5 (G1) and 5.0 (G2) kg of ground corn/head/day. Nitrogen content of diets were equalised using urea, to $12 \%$ of crude protein. The data involves more than 2500 animals, 100 or more per year, in completely randomised trial designs with replications. The final analysis was carried out by stepwise method, relating all the individual ADG with the average digestibility of bulky forages for each trial each year.

The regressions were : a) for $2.5 \mathrm{~kg} / \mathrm{head} /$ day supplement : -0.1677 + Digestibility $\times 0.01266$ $(\mathrm{r} 2=0.40) \quad(\mathrm{P}<0.0001)$ and $\mathrm{b})$ for 5.0 $\mathrm{kg} /$ head/day supplement : $0.2488+$ Digestibility $\times 0.00872(\mathrm{r} 2=0.14)(\mathrm{P}<0.01)$. At $5.0 \mathrm{~kg} / \mathrm{head} /$ day level of grain, forage digestibility had less influence in ADG.

Average daily gain $(\mathrm{kg} / \mathrm{d})$ according to DMIVD of forage and level of supplement

\begin{tabular}{lcc}
\hline & \multicolumn{2}{c}{ Supplement } \\
\cline { 2 - 3 } DMIVD of bulky forage & G1 & G2 \\
\hline Lowest $40.0 \%$ & 0.326 & 0.590 \\
Highest $68.9 \%$ & 0.704 & 0.850 \\
\hline
\end{tabular}

